\title{
Thyrotropin-Releasing Hormone (TRH) Inhibits Melanin-Concentrating Hormone Neurons: Implications for TRH-Mediated Anorexic and Arousal Actions
}

\author{
Xiaobing Zhang and Anthony N. van den Pol \\ Department of Neurosurgery, Yale University School of Medicine, New Haven, Connecticut 06520
}

\begin{abstract}
Thyrotropin-releasing hormone (TRH) increases activity and decreases food intake, body weight, and sleep, in part through hypothalamic actions. The mechanism of this action is unknown. Melanin-concentrating hormone (MCH) and hypocretin/orexin neurons in the lateral hypothalamus ( $\mathrm{LH})$ together with neuropeptide $\mathrm{Y}(\mathrm{NPY}$ ) and proopiomelanocortin (POMC) neurons in the arcuate nucleus play central roles in energy homeostasis. Here, we provide electrophysiological evidence from GFP-reporter transgenic mouse brain slices that shows TRH modulates the activity of MCH neurons. Using whole-cell current-clamp recording, we unexpectedly found that TRH and its agonist, montrelin, dose-dependently inhibited MCH neurons. Consistent with previous reports, TRH excited hypocretin/orexin neurons. No effect was observed on arcuate nucleus POMC or NPY neurons. The TRH inhibition of MCH neurons was eliminated by bicuculline and tetrodotoxin, suggesting that the effect was mediated indirectly through synaptic mechanisms. TRH increased spontaneous IPSC frequency without affecting amplitude and had no effect on miniature IPSCs or EPSCs. Immunocytochemistry revealed little interaction between TRH axons and MCH neurons, but showed TRH axons terminating on or near GABA neurons. TRH inhibition of MCH neurons was attenuated by $\mathrm{Na}^{+}-\mathrm{Ca}^{2+}$ exchanger (NCX) inhibitors, TRPC channel blockers and the phospholipase C inhibitor U-73122. TRH excited LH GABA neurons, and this was also reduced by NCX inhibitors. Finally, TRH attenuated the excitation of MCH neurons by hypocretin. Together, our data suggest that TRH inhibits MCH neurons by increasing synaptic inhibition from local GABA neurons. Inhibition of $\mathrm{MCH}$ neurons may contribute to the TRH-mediated reduction in food intake and sleep.
\end{abstract}

\section{Introduction}

Thyrotropin-releasing hormone (TRH) is a hypothalamic tripeptide hypophysiotropic hormone that was originally isolated as a releasing hormone that stimulated pituitary thyrotropin release and ultimately, thyroxin (Reichlin, 1989). Subsequently, TRH was also found in axons terminating on hypothalamic neurons, and in other regions of the brain (Lechan and Fekete, 2006). TRH has an important role in modulating energy homeostasis within the CNS (Lechan and Fekete, 2006). Central administration of TRH or TRH agonists consistently reduces food intake in normal rodents, hungry rats, and in models of stress-induced feeding (Vijayan and McCann, 1977; Vogel et al., 1979; Morley, 1980; Suzuki et al., 1982; Horita, 1998; Steward et al., 2003). TRH increases locomotor activity (Wei et al., 1975; Ervin et al., 1981) which also exerts an indirect effect on energy homeostasis (Castañeda et al., 2005). Additionally, TRH reduces sleep and cataplexy in narcoleptic animals (Nishino et al., 1997).

\footnotetext{
Received Nov. 30, 2011; revised Jan. 5, 2012; accepted Jan. 8, 2012.

Author contributions:X.Z. and A.N.v.d.P. designed research;X.Z. performed research;X.Z. analyzed data;X.Z. and A.N.v.d.P. wrote the paper.

Grant support was provided by NIH Grants NS41454, NS48476, and DK84052. We thank Yang Yang and Vitaliy Rogulin for technical assistance.

The authors declare no competing financial interests.

Correspondence should be addressed to Anthony N. van den Pol, Department of Neurosurgery, Yale University School of Medicine, 333 Cedar Street, New Haven, CT 06520. E-mail: anthony.vandenpo@yale.edu.

DOI:10.1523/JNEUROSCI.5966-11.2012

Copyright $\odot 2012$ the authors $\quad 0270-6474 / 12 / 323032-12 \$ 15.00 / 0$
}

Melanin-concentrating hormone $(\mathrm{MCH})$ is a cyclic 19-amino acid peptide (Saito et al., 1999) that is released by MCH neurons in the lateral hypothalamus ( $\mathrm{LH}) /$ perifornical area which project broadly throughout the brain (Bittencourt et al., 1992). Acting through its G-protein-coupled receptors MCHR1 and MCHR2 (MCH R2 receptors are found only in humans) (Forray, 2003), $\mathrm{MCH}$ can modulate activity in a large number of brain regions. Intracerebral injection of $\mathrm{MCH}$ increases feeding and body weight in rodents (Qu et al., 1996; Rossi et al., 1999); MCH mRNA expression is increased by fasting in normal rats or hypoleptinemic ob/ob mice (Presse et al., 1996; Qu et al., 1996). MCH analogs increase food intake (Suply et al., 2001) and chronic intracerebroventricular infusion of synthetic MCHR1 agonists induces obesity (Della-Zuana et al., 2002; Ito et al., 2003). Conversely, MCHR1 antagonists decrease food intake and body weight in both normal and diet-induced obese rats (Borowsky et al., 2002). These observations underline the essential role of $\mathrm{MCH}$ in modulating energy homeostasis. In addition, $\mathrm{MCH}$ cells play a role in the sleep-wake cycle. $\mathrm{MCH}$ neurons are sleep-active, but are quiet during periods of wakefulness (Verret et al., 2003; Hassani et al., 2009; Hassani et al., 2010). MCH agonists increase sleep (Lagos et al., 2009) whereas MCH antagonists reduce sleep (Ahnaou et al., 2008). MCH neurons are anatomically coextensive with neurons that synthesize hypocretin/orexin (Hcrt), which are wake-active and have been implicated in energy homeostasis and cognitive arousal (Sakurai et al., 1998; Lee et al., 2005). Recent reports showed a direct excitatory action of TRH on hypocretin neurons (González et al., 2009; Hara et al., 2009). 
A

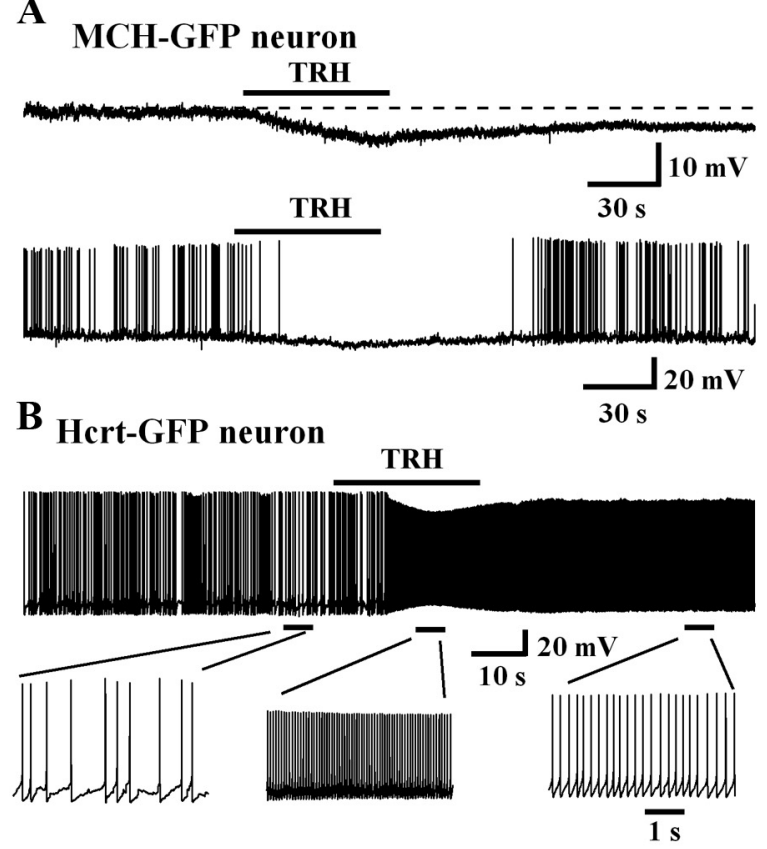

C POMC-GFP neuron

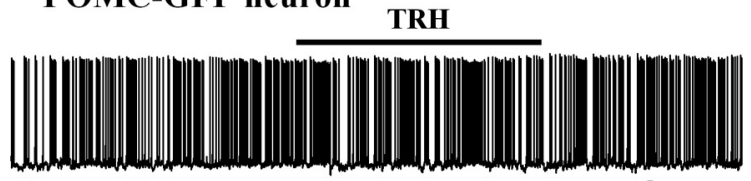

D NPY-GFP neuron

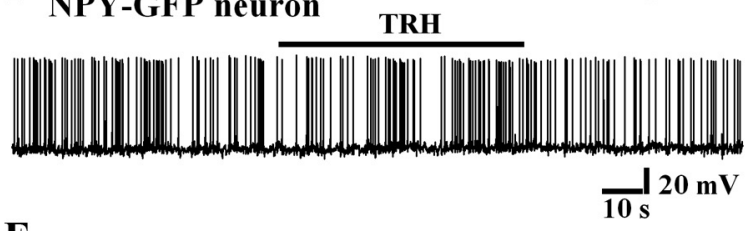

$\mathbf{E}$

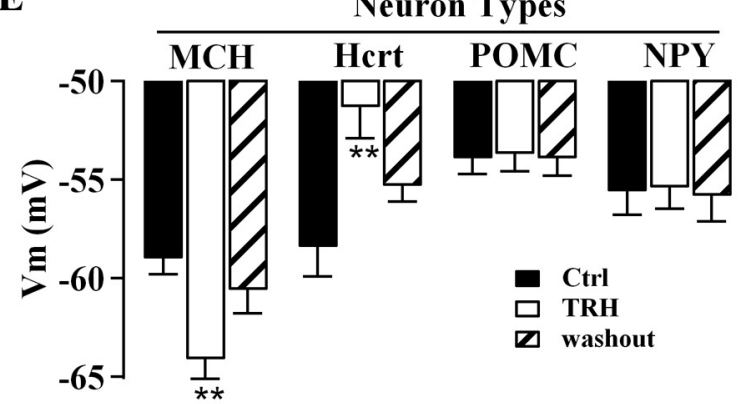

$\mathbf{F}$

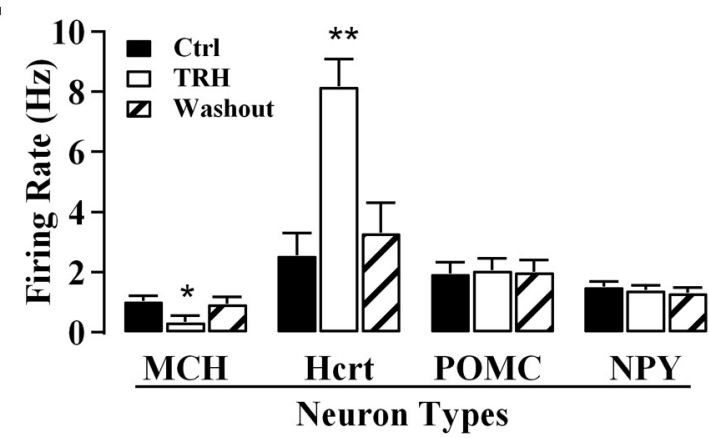

Figure 1. Differential effect of TRH on MCH and Hcrtneurons in the LH. $\boldsymbol{A}$, Representative traces show TRH (1 $\mu \mathrm{m})$ hyperpolarizes a silent MCH neuron [top; resting membrane potential (RMP), $-54 \mathrm{mV}$ ] and decreases spike frequency with hyperpolarization in an active neuron (bottom; RMP, $-51 \mathrm{mV}$ ). B, A representative trace showing TRH (1 $\mu \mathrm{M})$ excites Hcrt neurons (top) with expanded

To address the question of how TRH might influence hypothalamic neurons posited to modulate energy homeostasis, we investigated the effects of TRH on hypothalamic neurons that synthesize $\mathrm{MCH}, \mathrm{Hcrt}$, proopiomelanocortin (POMC), neuropeptide Y (NPY), or GABA using whole-cell patch-clamp recording in brain slices from a series of transgenic mice that express GFP in transmitter-select groups of neurons.

\section{Materials and Methods}

Brain slice preparation. To identify the correct cells from which to record, we used transgenic mice that express a GFP reporter in select neurons. The transgenic mice used included $\mathrm{MCH}$ GFP (van den Pol et al., 2004), hypocretin-GFP (Li et al., 2002), glutamate decarboxylase 67-GFP (GAD-GFP) (Acuna-Goycolea et al., 2005), POMC-GFP (Cowley et al., 2001) and NPY-GFP (van den Pol et al., 2009). Male and female mice aged 14-49 d old were used. Mice were housed in a climate-controlled environment at a temperature of $22^{\circ} \mathrm{C}$ with a $12 \mathrm{~h}$ light/dark cycle and ad libitum access to food and water. On the day of the experiment, mice were anesthetized with Nembutal $(100 \mathrm{mg} / \mathrm{kg})$ and decapitated. Brains were quickly removed and immersed in ice-cold high-sucrose solution containing (in $\mathrm{mm}$ ): 220 sucrose, $2.5 \mathrm{KCl}, 6 \mathrm{MgCl}_{2}, 1 \mathrm{CaCl}_{2}, 1.23$ $\mathrm{NaH}_{2} \mathrm{PO}_{4}, 26 \mathrm{NaHCO}_{3}, 10$ glucose and gassed with $95 \% \mathrm{O}_{2} / 5 \% \mathrm{CO}_{2} ; \mathrm{pH} 7.4$ with $\mathrm{NaOH}, 300$ $305 \mathrm{mOsm})$. Coronal brain slices (300 $\mu \mathrm{m}$ thick) were prepared using a vibratome to cut slices containing the hypothalamus. Slices were transferred to an incubation chamber filled with artificial CSF (ACSF) solution containing (in $\mathrm{mM}$ ): $124 \mathrm{NaCl}, 2.5 \mathrm{KCl}, 2 \mathrm{MgCl}_{2}, 2 \mathrm{CaCl}_{2}, 1.23$ $\mathrm{NaH}_{2} \mathrm{PO}_{4}, 26 \mathrm{NaHCO}_{3}$, and 10 glucose (gassed with $95 \% \mathrm{O}_{2} / 5 \% \mathrm{CO}_{2} ; \mathrm{pH} 7.4$ with $\mathrm{NaOH}, 300-$ $305 \mathrm{mOsm})$, and stored at room temperature $\left(22^{\circ} \mathrm{C}\right)$. After a $1-2 \mathrm{~h}$ recovery period, slices were transferred to a recording chamber mounted on a BX51WI upright microscope (Olympus). Slices were perfused with a continuous flow of gassed ACSF. Experiments were performed at $33 \pm 1^{\circ} \mathrm{C}$ using a dual-channel heat controller (Warner Instruments). All procedures in this study were ap-

$$
\leftarrow
$$

segments of the trace (bottom). RMP, $-59 \mathrm{mV}$. C, Representative trace showing no obvious effect of TRH $(1 \mu \mathrm{M})$ on membrane potential or spike frequency of a POMC neuron. RMP, $-58 \mathrm{mV}$. D, Representative trace showing no obvious effect of TRH $(1 \mu \mathrm{M})$ on membrane potential or firing rate of an NPY neuron. RMP, $-54 \mathrm{mV}$. $\boldsymbol{E}$, Bar graph showing the reversible hyperpolarization of the membrane potential of $\mathrm{MCH}$ neurons $(n=15)$, but reversible depolarization of Hcrt neurons ( $n=$ 6) by application of TRH $(1 \mu \mathrm{M})$. No significant effect was observed on membrane potential of POMC $(n=14)$ or NPY neurons $(n=12)$. $\boldsymbol{F}$, Summary of data showing TRH $(1 \mu \mathrm{M})$ reversibly decreases spike frequency of $\mathrm{MCH}$ neurons $(n=6)$ but increases spike frequency of Hcrt neurons $(n=6)$. The spike frequency of POMC $(n=14)$ or NPY $(n=12)$ neurons was not changed by TRH $(1 \mu \mathrm{M}) .{ }^{*} p<0.05,{ }^{* *} p<0.01$ compared with control, paired $t$ tests. Error bars indicate SEM. 
A

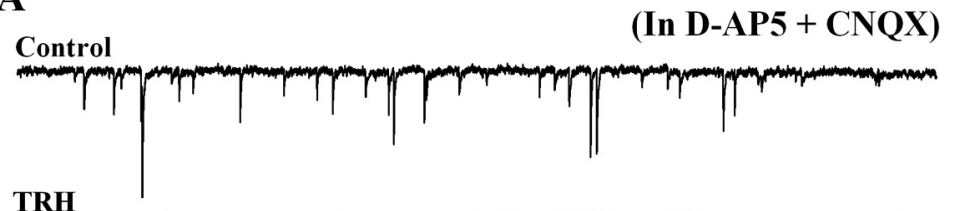

TRH

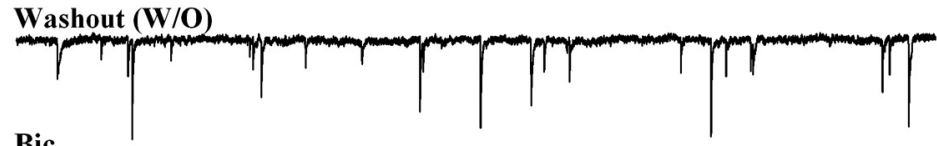

Bic

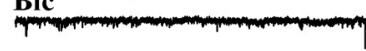

B

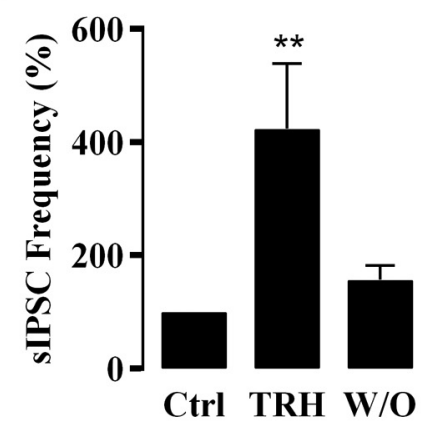

D

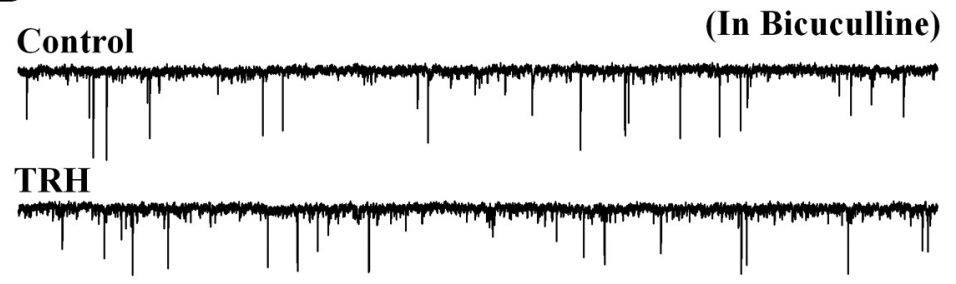

Washout (W/O)

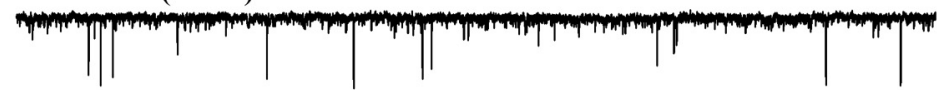

\section{AP-5 + CNQX}

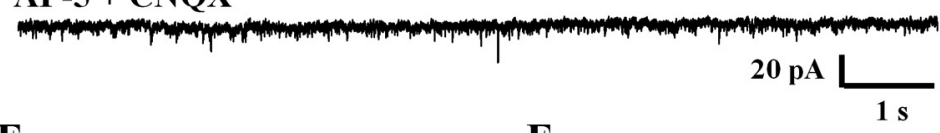

E

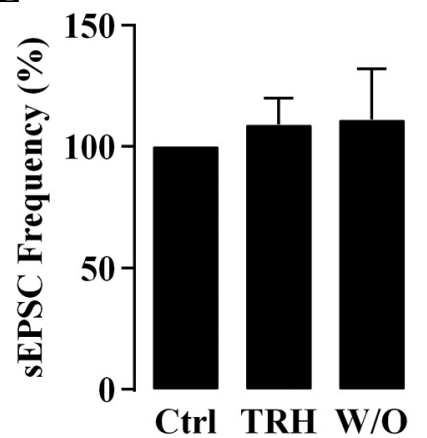

C

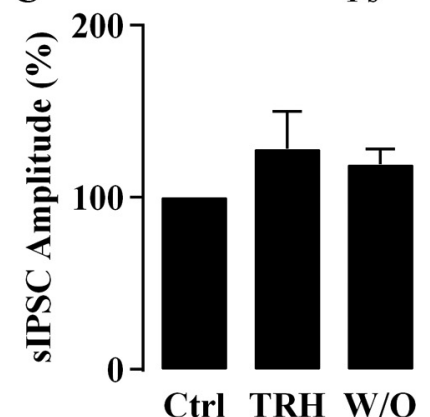

F

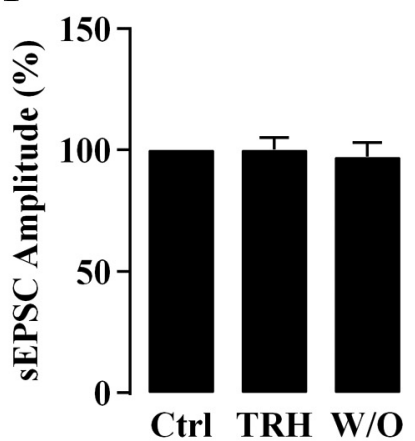

Figure 2. TRH increases spontaneous IPSC frequency. $\boldsymbol{A}$, Representative traces showing spontaneous IPSCs recorded from one MCH neuron before, during application of TRH $(1 \mu \mathrm{M})$, and after peptide washout in the presence of D-AP5 (50 $\mu \mathrm{M})$ and CNQX (10 $\mu \mathrm{M})$. Bic $(30 \mu \mathrm{m})$ blocked spontaneous IPSCs. B, Summary of data $(n=6)$ showing TRH $(1 \mu \mathrm{M})$ increases spontaneous IPSC

proved by the Yale University Committee on Animal Care and Use.

Patch-clamp recording. Whole-cell patch recordings were performed on GFP-expressing neurons that were visualized with a GFP filter set and an infrared-differential interference contrast optical system combined with a monochrome CCD camera and a monitor. Pipettes used for whole-cell recording were pulled from thin-walled borosilicate glass capillary tubes (length $75 \mathrm{~mm}$, outer diameter 1.5 $\mathrm{mm}$, inner diameter $1.1 \mathrm{~mm}$, World Precision Instruments) using a P-97 Flaming/Brown micropipette puller (Sutter Instruments) and had resistances ranging from 4 to $6 \mathrm{M} \Omega$ when filled with pipette solution containing (in $\mathrm{mm}$ ): 145 K-gluconate (or $\mathrm{KCl}$ for IPSCs), $1 \mathrm{MgCl}_{2}, 10$ HEPES, 1.1 EGTA, 2 Mg-ATP, 0.5 $\mathrm{Na}_{2}$-GTP, 5 $\mathrm{Na}_{2}$-phosphocreatine, $\mathrm{pH} 7.3$ with $\mathrm{KOH}$ (290-295 mOsm). Pipettes were connected via an $\mathrm{Ag}-\mathrm{AgCl}$ wire to the headstage of an EPC-10 patch-clamp amplifier (HEKA Instruments). The reference electrode was an $\mathrm{Ag}-\mathrm{AgCl}$ pellet (IVM) immersed in the bath solution. Pipette and cell capacitance were compensated for using PatchMaster 2.20 software (HEKA Elektronik). Neurons in which the series resistance was $>20 \mathrm{M} \Omega$ and changed $>15 \%$ were excluded from the statistics. PatchMaster 2.20 was used to acquire and analyze the data. Traces were processed using Igor Pro carbon 4.07 (WaveMetrics). Spontaneous and miniature postsynaptic currents were analyzed with MiniAnalysis 6.03 (Synaptosoft Inc.).

Immunocytochemistry. To determine whether TRH might be released by axon terminals near GABA or MCH neurons in the $\mathrm{LH}$, we combined immunocytochemistry with detection of GFP in GAD-GFP or MCH-GFP mice. Briefly, transgenic GFP-positive mice were anesthetized with sodium pentobarbital, and then perfused transcardially with saline followed by $4 \%$ paraformaldehyde. Sixteen micron thick coronal sections were cut on a cryostat, immersed in normal PBS for $15 \mathrm{~min}$ and then treated with 2\% normal horse serum in PBS for $30 \mathrm{~min}$, and then incubated overnight at $4^{\circ} \mathrm{C}$ in polyclonal rabbit anti-TRH antiserum (1:5000, kind gift from Dr T. Visser, Erasmus University Medical School, Rotterdam, The Netherlands) and described in detail previously (Klootwijk et al., 1995; González et al., 2009; Lyons et al., 2010). After washing $3 \times 10 \mathrm{~min}$ in PBS, sections were placed in secondary antisera of Alexa594 don-

\section{$\leftarrow$}

frequency. $C$, Summary of data $(n=6)$ showing normalized spontaneous IPSC amplitude in control, TRH (1 $\mu \mathrm{m})$ and washout period. $\boldsymbol{D}$, Representative traces showing spontaneous EPSCS recorded from another MCH neuron before, during application of TRH $(1 \mu \mathrm{M})$ and washout period in the presence of Bic $(30 \mu \mathrm{M})$. In the presence of D-AP5 (50 $\mu \mathrm{M})$ and CNQX (10 $\mu \mathrm{M})$, spontaneous EPSCs were completely blocked. $\boldsymbol{E}$, Summary of data ( $n=8)$ showing no significant effect of TRH (1 $\mu \mathrm{M})$ on spontaneous EPSC frequency. $\boldsymbol{F}$, Summary of data $(n=8)$ showing normalized spontaneous EPSC amplitude in control, TRH $(1 \mu \mathrm{M})$ and washout period. ${ }^{* *} p<0.01$ compared to control, paired $t$ test. 
A

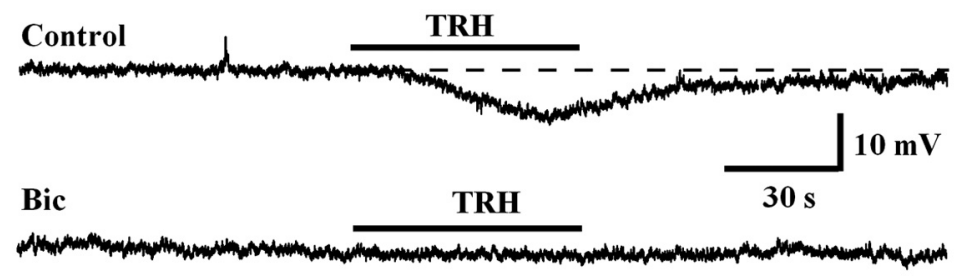

TTX TRH

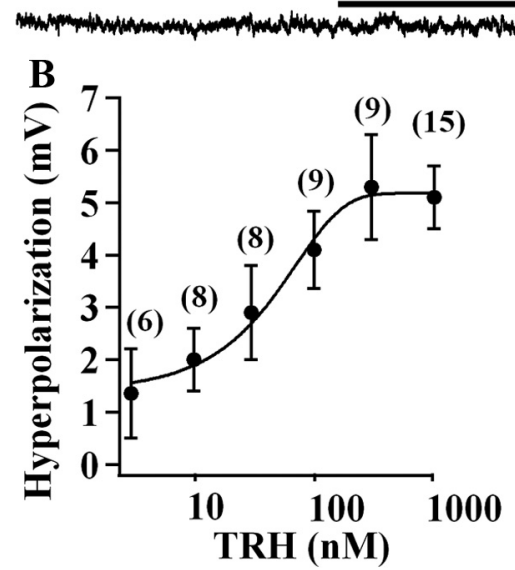

Figure 3. TRH inhibits MCH neurons indirectly by increasing presynaptic GABAergic inhibitory tone. $A$, Representative traces showing TRH effects on membrane potential of MCH neurons in normal buffer (RMP, $-58 \mathrm{mV})$. Bic ( $30 \mu \mathrm{M}$; RMP, $-56 \mathrm{mV}$ ) or TTX $(0.5 \mu \mathrm{m} ; \mathrm{RMP},-57 \mathrm{mV})$ block TRH actions on MCH cells. $\boldsymbol{B}$, The dose-dependent hyperpolarization effect of TRH on MCH neurons. C, Summary of data $(n=6-15)$ showing Bic and TTX both block the TRH-induced hyperpolarization of MCH neurons. ${ }^{* *} p<0.01$ compared with TRH without blockers.

key anti-rabbit IgG at a dilution of 1:200 for $30 \mathrm{~min}$, washed, and mounted on glass slides. Sections were studied on an Olympus IX70 inverted fluorescence microscope. Micrographs were recorded with a Spot digital camera (Diagnostic Imaging), and contrast and brightness were corrected using Photoshop CS4.

Statistical analysis. Data are expressed as mean \pm SEM. Group statistical significance was assessed using Student's $t$ test for comparison of two groups, and one-way ANOVA followed by a Bonferroni post hoc test for three or more groups. $p<0.05$ was considered statistically significant.

Drugs and drug application. TRH (human, rat, mouse), and hypocretin-2 (mouse, rat, porcine) were purchased from Phoenix Pharmaceuticals. Montirelin trifluoroacetate salt (montirelin) and U-73122 hydrate were from Sigma-Aldrich. Tetrodotoxin (TTX), bicuculline (Bic), 6-cyano-7-nitroquinoxaline-2,3-dione (CNQX), DL-2-amino-5-phosphonopentanoic acid (DAP5), SN-6, SKF96365, 2-APB, and KB-R7943 mesylate were obtained from Tocris Bioscience. All drugs were prepared and stored as stock solutions according to the manufacturer's instructions, and diluted in ACSF to obtain the experimental concentration for application before each experiment. All drug solutions were given by large diameter $(500 \mu \mathrm{m})$ flow pipe with the tip directed toward the recorded cell. During periods of no drug application, normal ACSF was continuously supplied to the recorded cell through the flow pipe.

\section{Results}

TRH exerts opposite actions on $\mathrm{MCH}$ and hypocretin neurons

Using whole-cell patch-clamp recording, we first examined the effects of TRH on $\mathrm{MCH}$ neurons in the $\mathrm{LH}$ /perifornical area. In current clamp, most $\mathrm{MCH}$ neurons were silent and the application of TRH $(1 \mu \mathrm{M})$ reversibly hyperpolarized the membrane potential from $-59.0 \pm 0.8 \mathrm{mV}$ to $-64.1 \pm 1.0 \mathrm{mV}$ and the membrane potential recovered to $-60.6 \pm 1.2 \mathrm{mV}$ after peptide washout (Fig. $1 A, E, n=15, p<0.01$, paired $t$ test). More than $80 \%$ (15 of 18 ) of $\mathrm{MCH}$ cells tested responded to $1 \mu \mathrm{M}$ TRH by hyperpolarization. Not all MCH neurons showed spontaneous spikes, but in those that did, TRH $(1 \mu \mathrm{M})$ decreased spike frequency from $1.0 \pm 0.2 \mathrm{~Hz}$ to $0.3 \pm 0.2 \mathrm{~Hz}$ (Fig. $1 A, F, n=6, p<0.05$, paired $t$ test); spikes recovered to $0.9 \pm 0.2$ $\mathrm{Hz}$ after peptide washout. Because TRH has generally been associated with excitatory actions, the TRH-mediated inhibition identified here was unexpected. As a control, we next recorded from nearby Hcrt neurons which were recently shown to be excited by TRH (González et al., 2009; Hara et al., 2009). Consistent with previous reports, TRH ( $1 \mu \mathrm{M})$ excited the Hcrt neurons (Fig. $1 B$ ), depolarizing the membrane potential from $-58.4 \pm 1.5$ $\mathrm{mV}$ to $-51.3 \pm 1.6 \mathrm{mV}$ (Fig. $1 E, n=6$, $p<0.01$, paired $t$ test) and increasing the spike frequency from $2.6 \pm 0.8 \mathrm{~Hz}$ to $8.2 \pm 0.9 \mathrm{~Hz}$ (Fig. $1 F, n=6, p<0.01$, paired $t$ test). These results indicate that TRH may modulate $\mathrm{MCH}$ neurons through a different mechanism than for Hcrt neurons.

Similar to MCH neurons, some cells in the hypothalamic arcuate nucleus-primarily orexigenic NPY neurons and anorexigenic POMC cells-are involved in energy homeostasis. We therefore tested whether TRH might modulate the activity of POMC and NPY neurons. TRH $(1 \mu \mathrm{M})$ had no apparent effect on the membrane potential of POMC neurons (pre-TRH: $-53.9 \pm 0.8 \mathrm{mV}$; in TRH: $-53.7 \pm 0.9 \mathrm{mV}$ ) (Fig. $1 C, E, n=14$, $p>0.05$, paired $t$ test) or spike frequency (pre-TRH: $1.9 \pm 0.4$ $\mathrm{Hz}$; in TRH: $2.1 \pm 0.4 \mathrm{~Hz}$ (Fig. $1 C, F, n=14, p>0.05$, paired $t$ test). Similarly, no obvious effect of TRH was observed on the activity of NPY neurons. Application of TRH $(1 \mu \mathrm{M})$ did not influence the membrane potential of NPY neurons (pre-TRH $-55.6 \pm 1.2 \mathrm{mV}$; in TRH $-55.4 \pm 1.1 \mathrm{mV}$ ) (Fig. $1 D, E, n=12$, $p>0.05$, paired $t$ test) or spike frequency (pre-TRH: $1.4 \pm 0.2$ $\mathrm{Hz}$; in TRH: $1.4 \pm 0.2 \mathrm{~Hz}$ ) (Fig. $1 D, F, n=12, p>0.05$, paired $t$ test).

TRH selectively increases GABA release onto $\mathrm{MCH}$ neurons $\mathrm{MCH}$ neurons are innervated primarily by GABA neurons, and this presynaptic GABAergic input may play a principal role in subserving neuronal communication to the $\mathrm{MCH}$ cell (van den Pol et al., 2004; Li and van den Pol, 2009). MCH cells express a number of GABA receptors, including $\mathrm{GABA}_{\mathrm{A}} \mathrm{R} \alpha 1$ (Harthoorn et al., 2005), $\alpha 2, \alpha 3$ (Bäckberg et al., 2004) and $\varepsilon$ (Moragues et al., 2003). To investigate the mechanism underlying the TRH inhibition of $\mathrm{MCH}$ neurons described above, we examined the effect of TRH on spontaneous IPSCs (sIPSCs) of MCH neurons. In the presence of D-AP5 $(50 \mu \mathrm{M})$ and CNQX $(10 \mu \mathrm{M})$ to eliminate spontaneous EPSCs (sEPSCs), we recorded sIPSCs that were completely blocked by the $\mathrm{GABA}_{\mathrm{A}}$ receptor antagonist bicuculline $(\mathrm{Bic}=30 \mu \mathrm{M}$; Fig. $2 A)$. TRH $(1 \mu \mathrm{M})$ significantly increased the IPSC frequency to $423 \pm 115 \%$ of control (Fig. $2 A, B, n=6$, $p<0.01$, paired $t$ test); the amplitude remained unaltered $(128 \pm$ 
$18 \%$ of control, Fig. $2 A, C, n=6, p>$ 0.05 , paired $t$ test). In the presence of Bic $(30 \mu \mathrm{M})$, we tested the effect of TRH on sEPSCs. TRH $(1 \mu \mathrm{M})$ had no obvious effect on sEPSC frequency $(109 \pm 11 \%$ of control, Fig. $2 D, E, n=8, p>0.05$, paired $t$ test) or amplitude (101 $\pm 5 \%$ of control, Fig. $2 D, F, n=8, p>0.05$, paired $t$ test). Together, these results indicate that TRH excites GABA neurons in synaptic contact with MCH cells.

TRH inhibition of $\mathrm{MCH}$ neurons is completely antagonized by blocking GABAergic inputs

Our experiments above were performed on $\mathrm{MCH}$ neurons from brain slices of young mice (postnatal day 14-21); we therefore tested whether TRH produces similar effects on $\mathrm{MCH}$ neurons from brain slices of adult mice (postnatal day 42-49). TRH (1 $\mu \mathrm{M})$ hyperpolarized the membrane potential by $4.6 \pm 0.5 \mathrm{mV}$ $(n=6)$ a magnitude of effect not statistically different from the value obtained using young mice $(5.1 \pm 0.6 \mathrm{mV}, n=15)$. We also recorded the effects of different concentrations of TRH on $\mathrm{MCH}$ neurons using doses ranging from $3 \mathrm{nM}$ to $1 \mu \mathrm{M}$ and found that TRH hyperpolarized $\mathrm{MCH}$ neurons in a dose-dependent manner (Fig. $3 B, n=55$ cells). We next tested whether TRH inhibits MCH neurons by a mechanism based on increased GABAergic inhibition through GABA release from presynaptic neurons. In the presence of Bic $(30 \mu \mathrm{M})$ to block all $\mathrm{GABA}_{\mathrm{A}}$ receptor-mediated inhibition, TRH $(1 \mu \mathrm{M})$ failed to hyperpolarize the membrane potential of $\mathrm{MCH}$ neurons $(0.1 \pm 0.2 \mathrm{mV}$ change, $n=7$, Fig. $3 A, C)$.

In the presence of TTX $(0.5 \mu \mathrm{M})$ to block transmitter release mediated by the excitation of presynaptic neurons, we tested the effect of TRH on the membrane potential of MCH neurons and found TRH $(1 \mu \mathrm{M})$ exerted no effect on $\mathrm{MCH}$ neurons (membrane potential changed by $0.1 \pm 0.2 \mathrm{mV}, n=7$, Fig. $3 \mathrm{~A}, C$ ). This result together with Bic blockade of TRH inhibition indicates that TRH inhibits MCH neurons through excitation of GABA neurons presynaptic to $\mathrm{MCH}$ cells.

\section{Lack of TRH effect on miniature IPSCs}

We next tested the effect of TRH on miniature IPSCs (mIPSCs) in the presence of TTX $(0.5 \mu \mathrm{M})$ to block spikes, and D-AP5 (50 $\mu \mathrm{M})$ and CNQX $(10 \mu \mathrm{M})$ to block glutamate receptor responses. As shown in Figure 4, neither the frequency nor the amplitude of mIPSCs was affected by TRH $(1 \mu \mathrm{M})$. These results suggest that TRH does not inhibit MCH neurons by acting on the axon terminals of presynaptic GABA neurons, but instead acts on GABAergic cell bodies/dendrites.

TRH excites neighboring GABA neurons in $\mathrm{LH}$

To ascertain whether TRH excites neighboring GABA neurons in the $\mathrm{LH} /$ perifornical area, we performed whole-cell patch recording on GAD-GFP neurons $(n=14)$ in this region. Seven of 14 neurons were strongly excited by TRH (Fig. 5A). TRH (1 $\mu \mathrm{M})$
MCH-GFP neuron
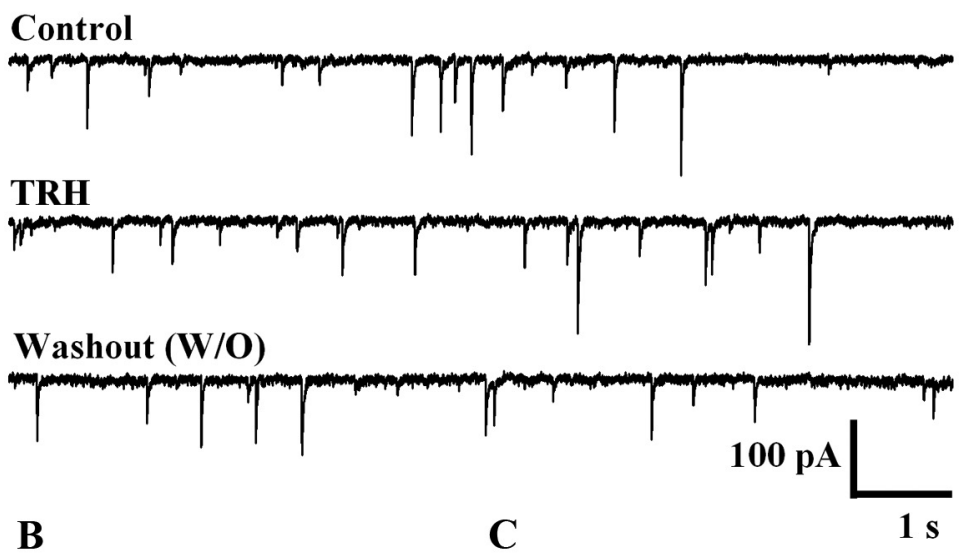

Figure 4. Lack of TRH effect on miniature IPSCS. A, Representative traces showing miniature IPSCS recorded from one MCH euron before, during and after application of TRH $(1 \mu \mathrm{M})$ in the presence of a mixture of TTX $(0.5 \mu \mathrm{M})$, D-AP5 $(50 \mu \mathrm{M})$ and CNQX $(10 \mu \mathrm{M})$. B, Summary of data $(n=7)$ showing no significant effect of TRH $(1 \mu \mathrm{M})$ on miniature IPSC frequency. C, Summary of data $(n=7)$ showing no significant effect of TRH $(1 \mu \mathrm{M})$ on miniature IPSC amplitude.

significantly depolarized the membrane potential from $-60.2 \pm$ $1.7 \mathrm{mV}$ to $-54.4 \pm 1.6 \mathrm{mV}$ (Fig. $5 B, C, n=7, p<0.05$, paired $t$ test) and increased the spike frequency from $0.5 \pm 0.2 \mathrm{~Hz}$ to $3.9 \pm$ $1.2 \mathrm{~Hz}$ (Fig. $5 B, D, n=7, p<0.01$, paired $t$ test). Additionally, we found that TRH inhibited 3 of 14 neurons, and had no obvious effect on another 4 neurons (Fig. $5 A$ ). To rule out the possibility that the TRH-mediated membrane potential change is random during recording with time, we compared the absolute change in membrane potential after $30 \mathrm{~s}$ treatment of ACSF or TRH. The absolute change of membrane potential found in control ACSF over $30 \mathrm{~s}$ was $0.5 \pm 0.1 \mathrm{mV}$. In contrast, after $30 \mathrm{~s}$ treatment of TRH $(1 \mu \mathrm{M})$, the absolute value of the membrane potential change was significantly altered by $4.1 \pm 1.0 \mathrm{mV}$ (Fig. $5 A, n=14$, $p<0.01$, paired $t$ test), confirming an action of TRH on the GABA neurons taken as an entire group $(n=14)$. The different response of GAD-GFP neurons to TRH suggests a diversity of GABA neuron responses in the LH. Based on reports that GAD and $\mathrm{MCH}$ are coexpressed in some $\mathrm{MCH}$ neurons (Elias et al., 2001), this result together with the TRH inhibition of MCH neurons raises the possibility that GAD-GFP neurons with an inhibitory response to $\mathrm{TRH}$ might be $\mathrm{MCH}$ neurons, or that other GABA neurons are inhibited by TRH indirectly in the same manner that MCH cells are. Thus, TRH excitation of the GABA neurons in this region is consistent with the view that TRH increases GABA release onto $\mathrm{MCH}$ neurons in the $\mathrm{LH}$.

To confirm that TRH directly activates GABA neurons in the $\mathrm{LH}$, we examined the effect of TRH $(1 \mu \mathrm{M})$ on membrane poten- 
tial of GABA neurons in the presence of TTX $(0.5 \mu \mathrm{M})$. In 8 of 13 cells, TRH $(1 \mu \mathrm{M})$ significantly depolarized the membrane potential from $-60.3 \pm 1.7 \mathrm{mV}$ to $-54.7 \pm 2.0 \mathrm{mV}$ (Fig. $5 E, F, n=8, p<$ 0.05 , paired $t$ test). This result confirms that TRH directly activates GABA neurons. None of the 13 cells tested showed any TRH-mediated hyperpolarization in the presence of TTX $(0.5 \mu \mathrm{M})$, suggesting the hyperpolarization effect by TRH found in the absence of TTX is through an indirect mechanism.

TRH inhibits MCH neurons by activating TRH receptor-related signaling pathway

Previous studies have shown that activation of TRH receptors excites neurons in other brain regions by activating phospholipase C (PLC) (Ishibashi et al., 2009) and the $\mathrm{Na}^{+}-\mathrm{Ca}^{2+}$ exchanger (NCX) (Parmentier et al., 2009). Therefore, we tested the effects of antagonists of PLC and the NCX on TRH inhibition of $\mathrm{MCH}$ neurons. First, we recorded the effect of montirelin, an agonist of the TRH receptor (Parmentier et al., 2009). Montirelin $(3 \mu \mathrm{M})$ mimicked the effect of TRH and hyperpolarized the membrane potential by $3.1 \pm 0.8 \mathrm{mV}$ (Fig. $6 B, n=6$ ).

To test whether PLC is involved in the inhibitory effect of TRH on $\mathrm{MCH}$ neurons, we measured the effect of TRH on the membrane potential of $\mathrm{MCH}$ neurons in the presence of U-73122, a PLC inhibitor. Application of TRH $(1 \mu \mathrm{M})$ in the presence of U-73122 (0.5 $\mu \mathrm{M})$ yielded an alteration in membrane potential of only $0.1 \pm 0.8 \mathrm{mV}$ (Fig. $6 B, n=7$ ) indicating $\mathrm{TRH}$ actions to inhibit $\mathrm{MCH}$ neurons were blocked under these conditions. Next, we tested whether NCX is involved in the TRH inhibition of $\mathrm{MCH}$ neurons using KB-R7943 (60 $\mu \mathrm{M})$, a nonselective NCX blocker. In the presence of KBR7943, TRH $(1 \mu \mathrm{M})$ had no effect on membrane potential $(0.0 \pm 0.4 \mathrm{mV})$ (Fig. $6 B, n=8$ ), indicating there was no hyperpolarization by TRH. KB-R7943 has been reported to block TRPC channels at this concentration (Kraft, 2007). Therefore, we tested the effect of SN-6, a NCX blocker reported to be more selective than KB-R7943 (Niu et al., 2007). In the presence of SN-6 $(10 \mu \mathrm{M})$, the TRH-induced hyperpolarization was attenuated to $2.1 \pm$ $0.4 \mathrm{mV}$ (Fig. $6 B, n=6$ ), suggesting that the NCX was responsible for part of the response, but that other mechanisms were also involved. TRPC channels have been suggested to be downstream of PLC in other hypothalamic neurons such as POMC cells (Qiu et al., 2010). To examine whether the TRPC channel is also involved in TRH in-

B

C

E

In TTX presence of TTX $(1 \mu \mathrm{m})$.
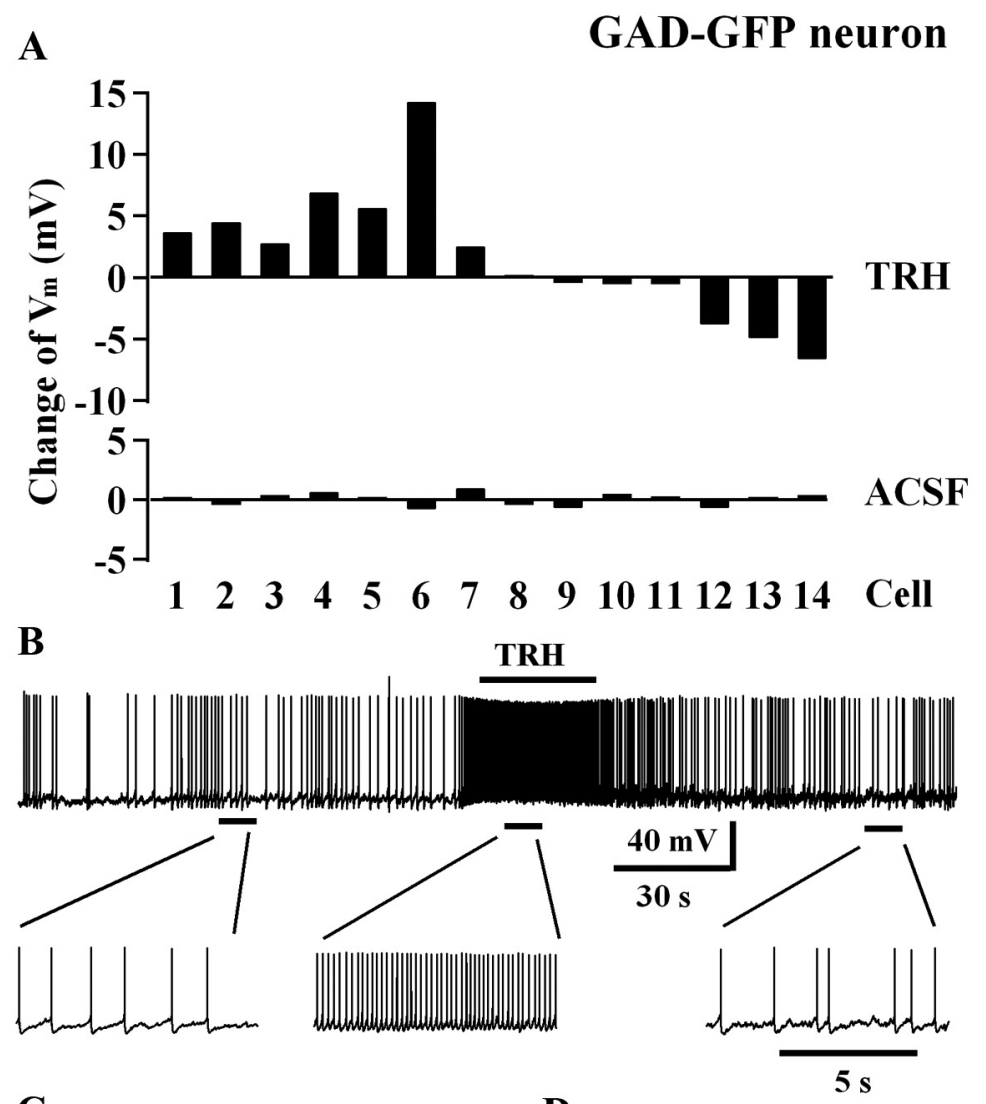

D
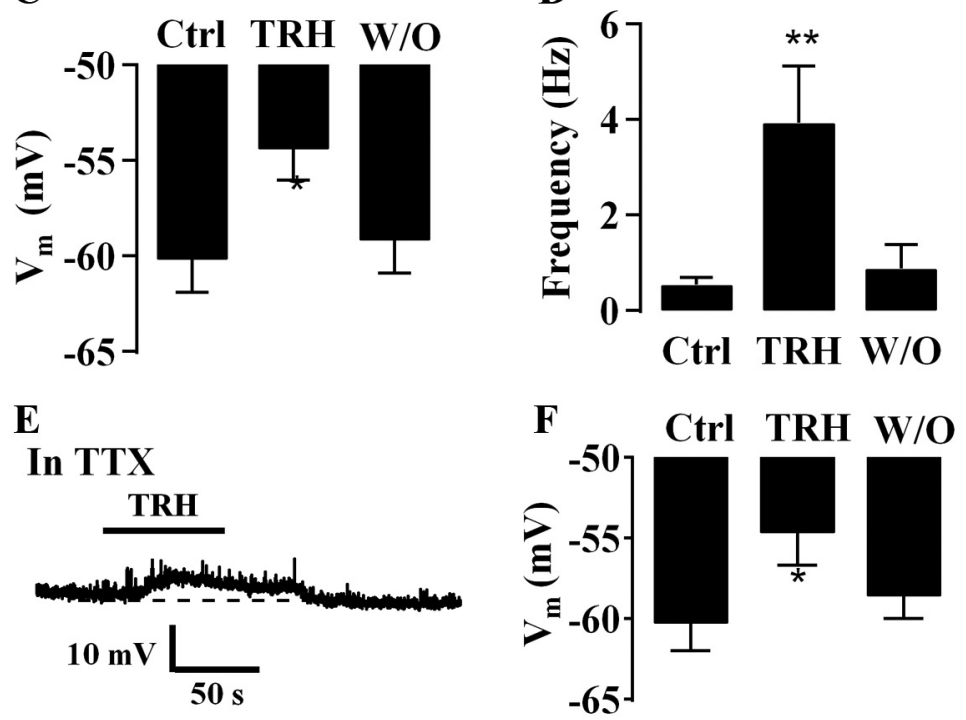

Figure 5. TRH excites neighboring GABA neurons in the LH. $\boldsymbol{A}$, Bars show the change in membrane potential in the 30 s after TRH application (top), and for the $30 \mathrm{~s}$ before TRH application (bottom) for each of the 14 GAD-GFP cells tested. In the $30 \mathrm{~s}$ after TRH application, a much greater shift in membrane potential was seen than in the $30 \mathrm{~s}$ before application. $\boldsymbol{B}, \mathrm{A}$ representative trace showing TRH (1 $\mu \mathrm{m}$ ) excites GAD-GFP neurons (top) in the LH with amplified segments of the trace (bottom). RMP, $-57 \mathrm{mV}$. C, Bar graph showing the reversible depolarization of the GAD-GFP neuron membrane potential $(n=6)$ by application of TRH (1 $\mu \mathrm{M})$. $\boldsymbol{D}$, Summary of data showing TRH $(1 \mu \mathrm{m})$ reversibly increases spike frequency $(n=6) .{ }^{*} p<0.05,{ }^{* *} p<0.01$ compared with control, paired $t$ tests. $\boldsymbol{E}$, Representative trace shows TRH-induced depolarization in the presence of TTX $(0.5 \mu \mathrm{M})$. RMP, $-65 \mathrm{mV}$. F, Bar graph showing the reversible depolarization of the GABA neuron membrane potential $(n=8)$ by application of TRH ( $1 \mu \mathrm{M})$ in the

hibition of $\mathrm{MCH}$ neurons, we measured the TRH effect on $\mathrm{MCH}$ neuron membrane potential in the presence of the TRPC channel blockers 2-APB or SKF96365. Extracellular 2-APB (100 $\mu \mathrm{M})$ reduced TRH-induced hyperpolarization of $\mathrm{MCH}$ neurons to 


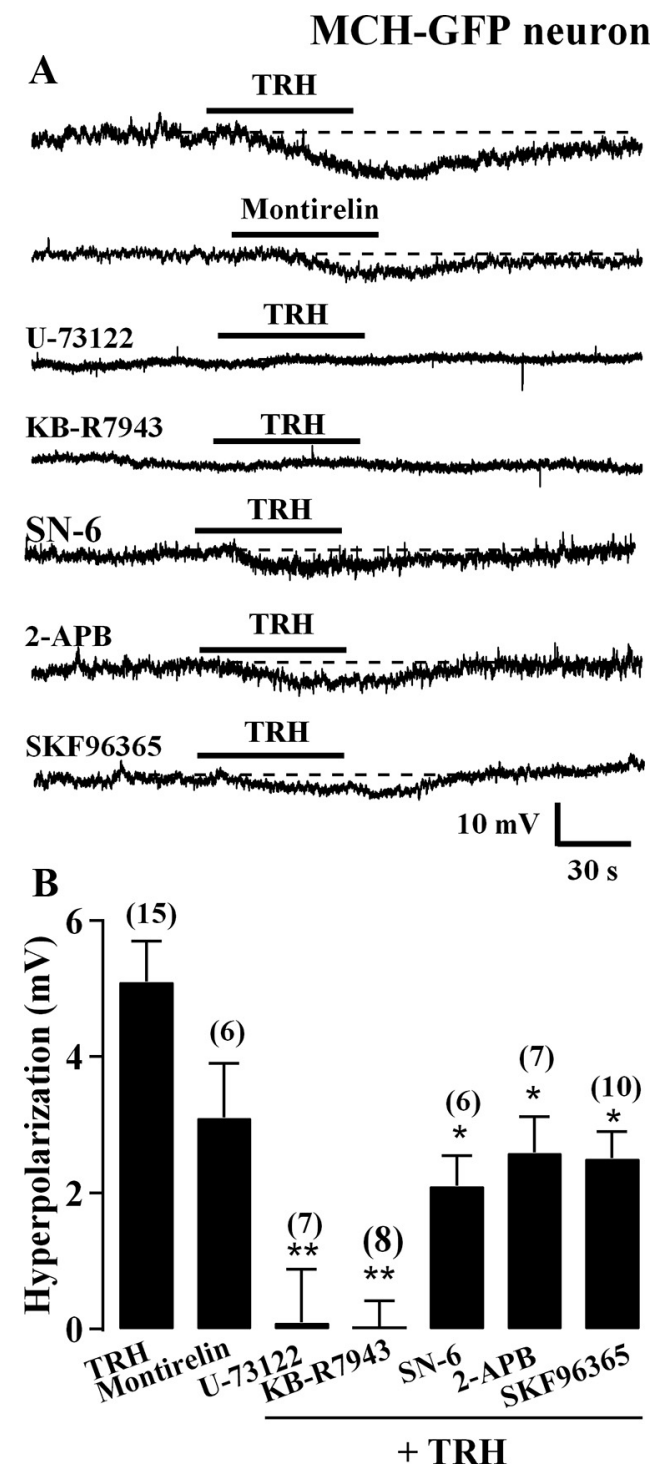

Figure 6. TRH hyperpolarizes $\mathrm{MCH}$ neurons through activation of the TRH receptor and its downstream signaling pathway. A, Representative traces showing TRH (1 $\mu \mathrm{m} ; \mathrm{RMP},-59 \mathrm{mV})$ and montirelin ( $3 \mu \mathrm{m}$; RMP, $-61 \mathrm{mV})$, a TRH receptor agonist, both hyperpolarize MCH neurons. U-73122 (0.5 $\mu \mathrm{m} ; \mathrm{RMP},-54 \mathrm{mV})$ and KB-R7943 $(60 \mu \mathrm{m} ; \mathrm{RMP},-60 \mathrm{mV})$ both block TRH-mediated hyperpolarization. SN-6 (10 $\mu \mathrm{m}$; RMP, $-59 \mathrm{mV}), 2-\mathrm{APB}(100 \mu \mathrm{m} ; \mathrm{RMP},-59$ $\mathrm{mV})$ and SKF96365 (30 $\mu \mathrm{m}$; RMP, $-59 \mathrm{mV})$ attenuate TRH-mediated hyperpolarization. $\boldsymbol{B}$, Summary of data showing montirelin $(n=6)$ mimics the hyperpolarization effect of TRH ( $n=$ 13), whereas U-73122 $(n=7)$ and KB-R7943 $(n=8)$ block the TRH effect on MCH neurons. SN-6 $(n=6), 2-\mathrm{APB}(n=7)$ and SKF96365 $(n=10)$ all attenuate the TRH effect on MCH neurons. ${ }^{*} p<0.05$ and ${ }^{* *} p<0.01$ versus TRH effect without antagonists.

$2.9 \pm 0.5 \mathrm{mV}$ (Fig. $6 B, n=7$ ), suggesting that TRPC channels contribute to TRH inhibition of $\mathrm{MCH}$ neurons. To further confirm this, we examined the effect of SKF96365, another potent TRPC channel blocker. In the presence of SKF96365 (30 $\mu \mathrm{M})$, $\mathrm{TRH}$-induced hyperpolarization of $\mathrm{MCH}$ neurons was attenuated to $2.5 \pm 0.4 \mathrm{mV}$ (Fig. $6 B, n=10$ ). Together, these results suggest that both NCX and TRPC channels, which are located downstream of PLC, contribute to the TRH inhibition of $\mathrm{MCH}$ neurons.

Mechanism for TRH activation of LH GAD-GFP neurons To further confirm the mechanisms underlying the TRH effect revealed by the study of $\mathrm{MCH}$ neurons described above, we per- formed parallel experiments to test GAD-GFP neurons directly. In the presence of TTX $(0.5 \mu \mathrm{M})$, D-AP5 $(50 \mu \mathrm{M})$, CNQX $(10 \mu \mathrm{M})$ and Bic $(30 \mu \mathrm{M}), \mathrm{TRH}(1 \mu \mathrm{M})$ evoked an obvious inward current with a mean value of $9.8 \pm 1.9$ pA (Fig. $7 A, B, n=10$ ). When U-73122 (0.5 $\mu \mathrm{M}), \mathrm{KB}-\mathrm{R} 7943(60 \mu \mathrm{M}), \mathrm{SN}-6(10 \mu \mathrm{M})$ or SKF96365 were applied in the bath solution, the current was inhibited to $1.9 \pm 1.2 \mathrm{pA}(n=6), 1.8 \pm 1.0 \mathrm{pA}(n=7), 3.5 \pm 1.5$ $\mathrm{pA}(n=9)$ and $4.6 \pm 1.0 \mathrm{pA}(n=9)$ respectively (Fig. $7 A, B)$. These results indicated that the TRH-induced current was almost completely inhibited by U-73122 $(0.5 \mu \mathrm{M})$, indicating that PLC contributes to TRH activation of GABA neurons. In addition, TRH-activated current was almost completely inhibited by KBR7943 $(60 \mu \mathrm{M})$ and partially inhibited by SN-6 $(10 \mu \mathrm{M})$ or SKF96365 $(30 \mu \mathrm{M})$, further confirming that both NCX and TRPC channels were involved in TRH activation of GABA. To further address the underlying mechanism of TRH action on GABA neurons, we next used voltage ramps. The TRH-evoked currents were tested using a ramp voltage protocol from -130 to $-20 \mathrm{mV}$ starting from a holding potential of $-60 \mathrm{mV}$. With the perfusion of normal ACSF with TTX $(0.5 \mu \mathrm{M})$, D-AP5 (50 $\mu \mathrm{M})$, CNQX (10 $\mu \mathrm{M}), \mathrm{Bic}(30 \mu \mathrm{M})$ and $\mathrm{Cd}^{2+}(200 \mu \mathrm{M})$, using K-gluconate in the pipette solution, the ramp induced a current response as shown in Figure $7 C$; TRH $(1 \mu \mathrm{M})$ increased the current evoked by this ramp protocol. After subtracting the current of the control from that of TRH, a TRH-evoked current was obtained (Fig. 7D). The reversal potential was $-26 \pm 2 \mathrm{mV}(n=4)$, consistent with TRH activation of both NCX and TRPC channels.

We next investigated the current-voltage relationship before and after applying TRH $(1 \mu \mathrm{M})$ by injecting a series of square wave currents from -80 to $0 \mathrm{pA}$. The input resistance was calculated based on the linear part of the current-voltage relationship curve (Fig. 7E1-E3). TRH (1 $\mu \mathrm{M})$ reduced the input resistance from $717.9 \pm 15.1 \mathrm{M} \Omega$ to $617.7 \pm 9.8 \mathrm{M} \Omega(p<0.05, n=5$, paired $t$ test). These results confirm that TRH not only activates NCX as demonstrated by the above results, but also directly opens ion channels on GABA neurons which would lead to a reduction in input resistance, consistent with the opening of TRPC channels.

\section{TRH attenuates hypocretin excitation of $\mathrm{MCH}$ neurons}

Hypocretin axons directly innervate $\mathrm{MCH}$ neurons (Guan et al., 2002; van den Pol et al., 2004) and the hypocretin peptide (hypocretin-2, Hcrt-2) excites MCH cells (van den Pol et al., 2004). We asked whether TRH antagonizes the Hcrt-induced excitation of $\mathrm{MCH}$ neurons through an increase of GABA inhibition. In one group of $\mathrm{MCH}$ neurons, Hcrt-2 (1 $\mu \mathrm{M})$ depolarized the membrane potential of $\mathrm{MCH}$ neurons by $3.3 \pm 0.9 \mathrm{mV}$ after $1 \mathrm{~min}$ and $4.2 \pm 1.1 \mathrm{mV}$ after a 2 min exposure (Fig. $8 A, C, n=7$ ). No significant difference was found in the level of depolarization between 1 and 2 min of Hcrt-2 treatment. In another group of neurons, Hcrt-2 (1 $\mu \mathrm{M})$ produced a similar level of depolarization $(3.6 \pm 0.9 \mathrm{mV})$ at $1 \mathrm{~min}$ after treatment. In the second minute, we added TRH $(1 \mu \mathrm{M})$ to the Hcrt-2 $(1 \mu \mathrm{M})$ solution. TRH addition antagonized the Hcrt-induced depolarization and Hcrt evoked only a $0.3 \pm 0.8 \mathrm{mV}$ change in the presence of TRH $(p<0.05$ compared with the $3.6 \mathrm{mV}$ depolarization evoked by Hcrt with no TRH, $n=11$, Fig. $8 A, C)$. In MCH neurons that showed action potentials, Hcrt-2 $(1 \mu \mathrm{M})$ increased the spike frequency from $0.7 \pm 0.3 \mathrm{~Hz}$ to $3.0 \pm 1.2 \mathrm{~Hz}(p<0.05, n=5$, Fig. $8 B, D)$. TRH $(1 \mu \mathrm{M})$ addition to Hcrt-2 $(1 \mu \mathrm{M})$ attenuated the increase in spike frequency $(1.0 \pm 0.5 \mathrm{~Hz} ; n=5 ; p<0.05$ compared with $3 \mathrm{~Hz}$ with Hcrt alone; Fig. $8 B, C$ ). Together, these 


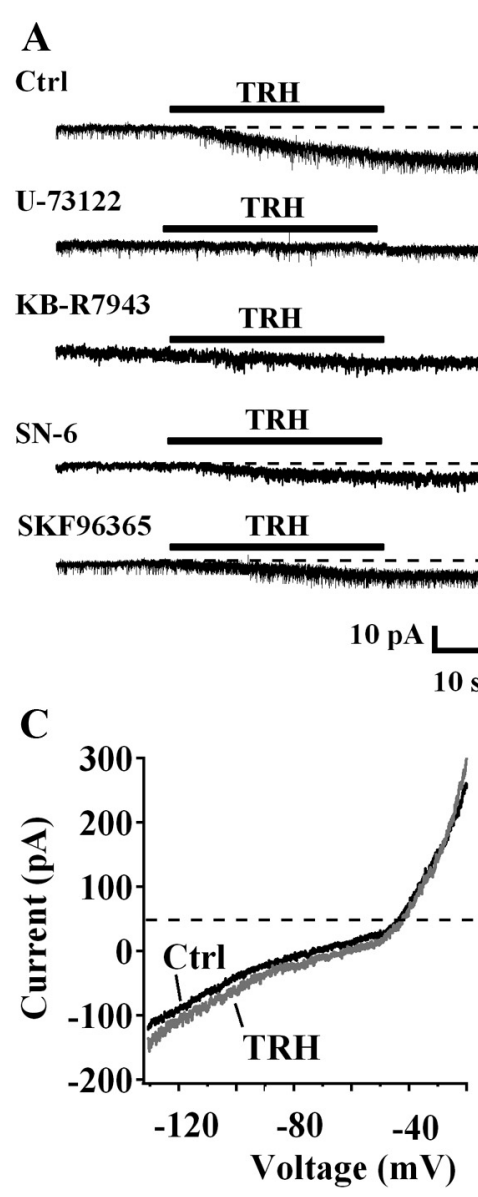

E1

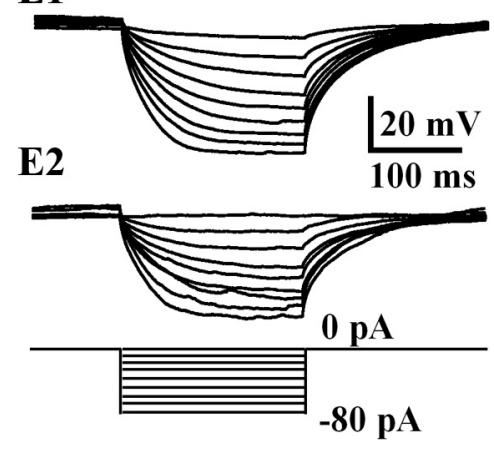

GAD-GFP neuron

B

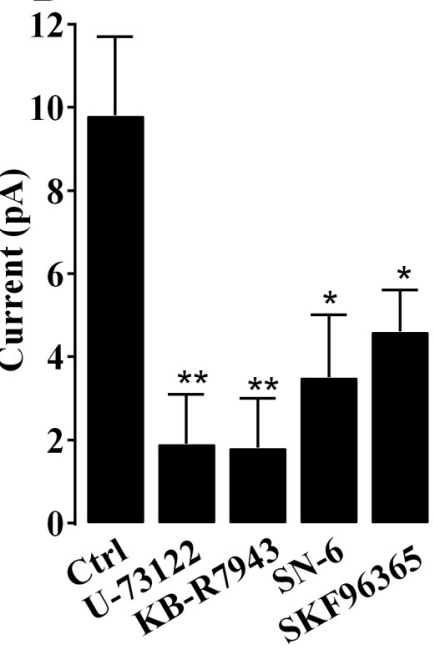

D

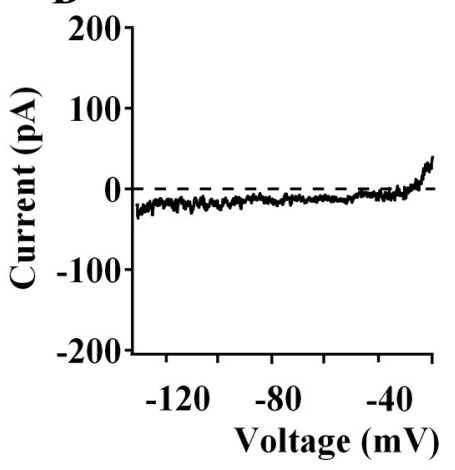

E3

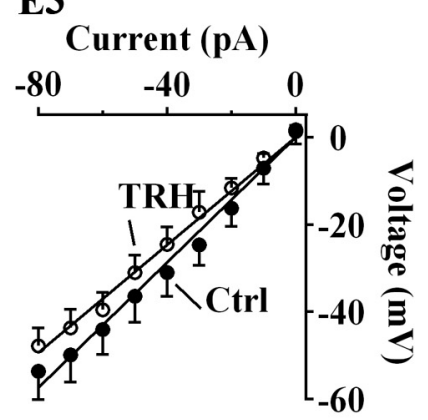

Figure 7. Mechanism for TRH activation of GABA neurons. $A$, Representative traces showing TRH (1 $\mu \mathrm{M})$-induced current in the absence and presence of U-73122 $(0.5 \mu \mathrm{M})$, KB-R7943 $(60 \mu \mathrm{M}), \mathrm{SN}-6(10 \mu \mathrm{M})$, and SKF96365 $(30 \mu \mathrm{M})$. The currents were recorded in the presence of TTX $(0.5 \mu \mathrm{M}), \mathrm{D}-\mathrm{AP} 5(50 \mu \mathrm{M}), \mathrm{CNQX}(10 \mu \mathrm{M})$, and Bic $(30 \mu \mathrm{M})$. Membrane potential was held at $-60 \mathrm{mV}$ for all cells during these voltage-clamp experiments. $\boldsymbol{B}$, Bar graph showing the mean amplitude of TRH-induced current in various conditions as shown in $\boldsymbol{A} .{ }^{*} p<0.05,{ }^{* *} p<0.01$ compared with Ctrl. C, Representative current traces evoked by voltage ramp from -130 to $-20 \mathrm{mV}$ during perfusion of normal ACSF solution (Ctrl) and TRH in the same GAD-GFP neuron with K-gluconate in the pipette solution. During the whole recording, TTX $(0.5 \mu \mathrm{M}), \mathrm{D}-\mathrm{AP5}(50 \mu \mathrm{M}), \mathrm{CNQX}(10 \mu \mathrm{M}), \mathrm{Bic}(30 \mu \mathrm{M})$ and $\mathrm{Cd}^{2+}(200 \mu \mathrm{M})$ were used in the ACSF. D, The TRH-induced current (subtraction of (trl from TRH). E1-E3, Response of GAD-GFP neurons to current injection from -80 to $0 \mathrm{pA}$ in the presence of TTX $(0.5 \mu \mathrm{M}), \mathrm{D}-\mathrm{AP} 5(50 \mu \mathrm{M}), \mathrm{CNQX}(10 \mu \mathrm{M})$ and Bic $(30 \mu \mathrm{M})$. Representative traces from a GAD-GFP neuron before (E1) and during (E2) application of TRH $(1 \mu \mathrm{M})$ and current-voltage relationship from 5 neurons before and during application of TRH $(1 \mu \mathrm{M})(\boldsymbol{E} 3)$.

results indicate that TRH antagonized the hypocretin excitation of $\mathrm{MCH}$ neurons.

TRH axons abut GABA cells, but not $\mathrm{MCH}$ cells

TRH axons were immunostained red with Alexa 594. As reported previously (Nishiyama et al., 1985), TRH-immunoreactive axons are found in many regions of the medial hypothalamus, with a particularly high density in the dorsomedial nucleus. In addition, there are regions of the LH that also contain relatively high densities of immunoreactive axons, and other regions of the LH with relatively few immunoreactive axons. In general there was a medial to lateral decrease in the density of TRHimmunoreactive axons, with the fewest axons and boutons found in the most lateral region of the LH (Figs. 9, 10D). Although a small number of errant TRHimmunoreactive axons trespassed near $\mathrm{MCH}$ cells, particularly in the most medial $\mathrm{MCH}$ neurons, we found little overlap between green $\mathrm{MCH}$ cells visualized by GFP expression in sections from $\mathrm{MCH}-\mathrm{GFP}$ transgenic mice, and red TRH axons (Figs. 9, 10C). This is consistent with the lack of direct response of $\mathrm{MCH}$ cells to TRH, described above. In contrast, when we examined sections from a GADGFP mouse, we found a high frequency of appositions between red immunoreactive TRH axons and green GABA cells (Fig. $10 A, B)$ in some, but not all, regions of the LH. A semiquantitative analysis of TRHimmunoreactive bouton density showed a higher density in LH/perifornical regions rich in GAD-GFP cells, and fewer in regions of high MCH cell density (Fig. 10D).

\section{Discussion}

In the present study, we found that TRH produced an unexpected inhibitory action on MCH neurons. Using whole-cell recording, we showed an indirect hyperpolarizing action of TRH on $\mathrm{MCH}$ neurons that was blocked by TTX and the $\mathrm{GABA}_{\mathrm{A}}$ receptor antagonist bicuculline. $\mathrm{TRH}$ strongly activated presynaptic GABA neurons and increased GABA release onto $\mathrm{MCH}$ neurons. TRH-immunoreactive axons terminated on or near GABA (GADGFP) neurons in the $\mathrm{LH}$, but not on $\mathrm{MCH}$ cells. The inhibitory effect of TRH recorded in MCH neurons was mimicked by the TRH agonist montirelin and blocked by antagonists of PLC, NCX and TRPC. In parallel, TRH activation of GABA neurons was inhibited by antagonists of PLC, NCX and TRPC, further confirming the involvement of an intracellular signaling pathway from TRH receptor to downstream PLC activation that opened TRPC channels and activated the NCX. Together, these results demonstrate that TRH inhibits MCH neurons indirectly by increasing GABAergic inhibition.

\section{Mechanisms for TRH action}

The primary synaptic input to $\mathrm{MCH}$ neurons in the $\mathrm{LH}$ is GABAergic, underlining the strong contribution of inhibitory 
signaling here (van den Pol et al., 2004; Li and van den Pol, 2009). Thus, functional modulation targeting presynaptic GABA neurons may have a high impact on the activity of $\mathrm{MCH}$ neurons. Immunoreactive TRH fibers and synaptic boutons have been described in the LH (Lechan and Jackson, 1982; Nishiyama et al., 1985; Lechan et al., 1986; González et al., 2009). Our immunocytochemistry results show that TRH-immunoreactive axons terminate on or near GABA cells in the LH and dorsomedial nucleus; in contrast, relatively few TRH axons are found near $\mathrm{MCH}$ cells or dendrites. TRH strongly excited a subpopulation of GABA neurons in the $\mathrm{LH}$. MCH neurons have been reported to be GABAergic because GAD and $\mathrm{MCH}$ are coexpressed in some $\mathrm{MCH}$ neurons (Elias et al., 2001). We found no excitatory effect of TRH on MCH neurons, suggesting that TRH excites specific GABA neurons other than those coexpressing GAD and MCH. TRH increased sIPSC frequency without affecting miniature IPSC frequency, similar to reports in Hcrt neurons (Hara et al., 2009). These findings suggest that TRH activates a subpopulation of GABA neurons to increase GABA release onto $\mathrm{MCH}$ neurons; we found no evidence for TRH actions on presynaptic axon terminals contacting $\mathrm{MCH}$ cells. The view that a GABA neuron in the $\mathrm{LH}$ is responsible for producing the TRH inhibition of MCH neurons is supported by the evidence that TRH inhibition was blocked by the $\mathrm{GABA}_{\mathrm{A}}$ receptor antagonist bicuculline and by blocking spike-dependent transmitter release with TTX. Since the TRH effect did not appear to be mediated directly at the presynaptic terminal, but rather on cell bodies, the cell bodies were most likely neighboring GABA cells in the same brain slice. If the GABA cells were far away, it is likely that the axons would have been severed during slice preparation. An additional possibility is that GABA neu-

rons in the dorsomedial hypothalamic nucleus that receive TRH innervation, and are potentially contained in the same brain slice as the recorded cell, might contribute to this indirect effect.

TRH-inhibitory effects on MCH neurons were mimicked by the TRH analog montirelin, confirming activation of TRH receptors. The TRH-mediated excitation of local GABA neurons was blocked by U-73122, suggesting a phospholipase C-dependent excitation. TRH actions were also blocked by KB-R7943 and attenuated by SN-6, 2-APB and SKF96365 suggesting a mechanism based on an activation of both NCX and TRPC channels. In contrast to the mechanisms we identified in $\mathrm{MCH}$ and GABA cells, TRH excited Hcrt neurons through a $\mathrm{Na}^{+}$-dependent depolarization and activation of a mixed cation current (González et al., 2009). Similar to GABA neurons in the LH, TRH was re-

\section{MCH-GFP neuron}

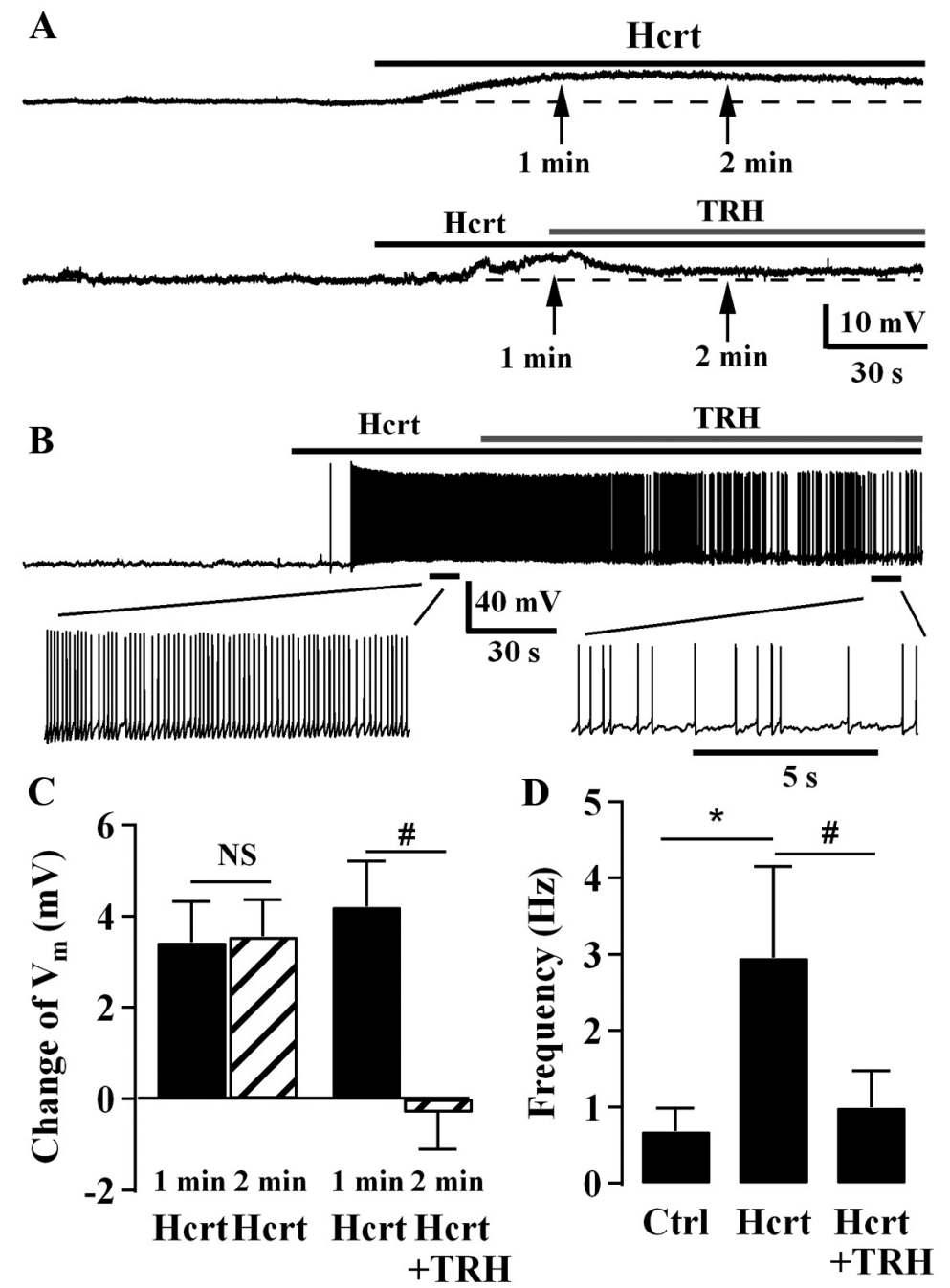

Figure 8. TRH antagonizes hypocretin-induced excitation of MCH neurons. $\boldsymbol{A}$, Representative trace shows Hcrt (1 $\mu \mathrm{M})$ depoarization from another MCH neuron. $\boldsymbol{B}$, Representative trace shows TRH (1 $\mu \mathrm{M})$ antagonizes Hcrt-induced depolarization and

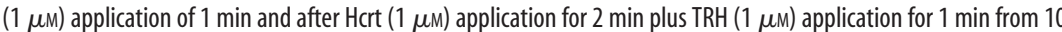
cation of Hcrt $(1 \mu \mathrm{M})$ and TRH $(1 \mu \mathrm{M})$. NS, no significant difference; ${ }^{*} p<0.05$ compared between Hcrt treatment with control without any treatment, paired $t$ test; ${ }^{\#} p<0.05$ compared between $\mathrm{Hcrt}$ treatment and Hort plus TRH treatment, paired $t$ test.

ported to excite posterior hypothalamic histamine neurons through multiple mechanisms (Parmentier et al., 2009).

Functional relevance to energy homeostasis and arousal TRH plays a role in a variety of biological hypothalamic functions (Lechan and Fekete, 2006) including feeding and metabolism. Central administration of TRH or TRH analogs reduces food intake within $30 \mathrm{~min}$ of application (Vijayan and McCann, 1977; Vogel et al., 1979; Morley, 1980; Suzuki et al., 1982; Horita, 1998; Steward et al., 2003), suggesting an involvement of TRH circuits in the inhibition of food intake and reduction of body weight. Our present study indicates that TRH strongly inhibits MCH neuronal activity. We also corroborate earlier reports that TRH excites Hcrt neurons (González et al., 2009; Hara et al., 2009).

TRH-immunoreactive axons innervate the arcuate nucleus; arcuate NPY and POMC neurons modulate energy homeostasis 


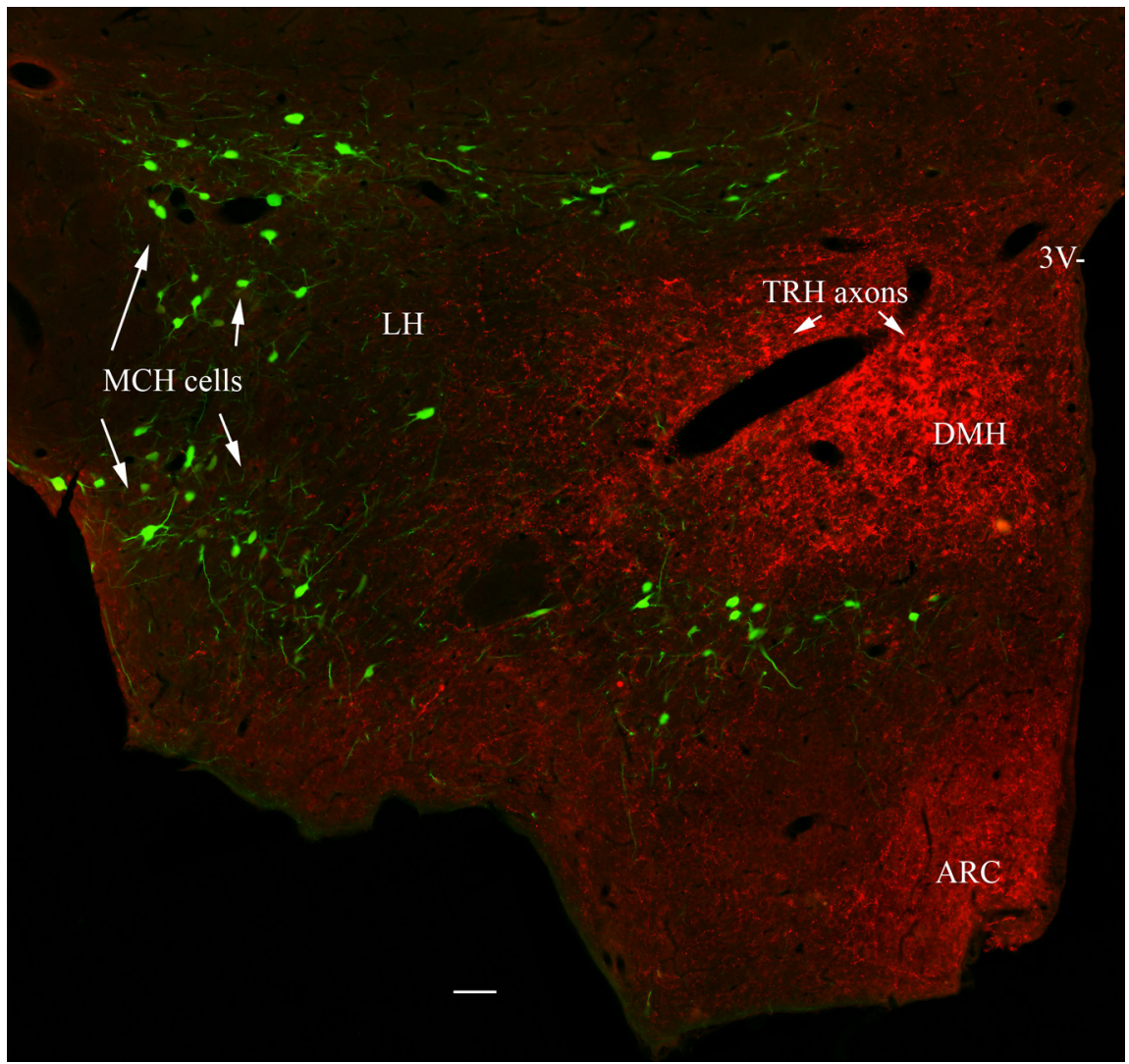

Figure 9. Paucity of overlap of TRH axons and MCH neurons. This photomicrograph taken with a laser confocal microscope shows green MCH neurons that express GFP, and TRH axons immunostained red in the left hypothalamus. Only a modest overlap of the TRH and MCH immunoreactivity is found. DMH, Dorsomedial nucleus; ARC, arcuate nucleus; 3V, third ventricle. Scale bar, $180 \mu \mathrm{m}$.

and could potentially respond to TRH. However, we found no detectable effect of TRH on POMC or NPY neurons using the same concentration of TRH that excited Hcrt cells and inhibited $\mathrm{MCH}$ cells. Both NPY and POMC cells project to paraventricular nucleus (PVN) TRH cells (Légrádi and Lechan, 1998). Furthermore, leptin increases TRH synthesis and release by directly activating leptin receptors on TRH cells in the PVN (Elmquist et al., 1998; Nillni et al., 2000) and indirectly by activating leptin receptor-expressing POMC neurons in the arcuate nucleus that in turn release $\alpha$-MSH to stimulate TRH neurons expressing the MC4 receptor (Perello et al., 2006). NPY inhibits TRH synthesis in the PVN through activation of NPY receptors on TRH neurons (Légrádi and Lechan, 1998; Fekete et al., 2000, 2001). Thus, although the POMC and NPY cells may not respond directly to TRH, both cell types still may modulate TRH release. MCH neurons may play a crucial role in signaling downstream from the leptin receptor (Segal-Lieberman et al., 2003).

The hypocretin cell has been suggested to play an orexigenic role in energy homeostasis (Sakurai et al., 1998); since TRH excited the presumptive orexigenic hypocretin cell, it is unlikely that the TRH-mediated reduction in food intake is through TRH actions on the hypocretin cell. Together with the apparent lack of effect of TRH on POMC and NPY neurons, and the excitatory actions on hypocretin neurons, $\mathrm{MCH}$ neurons might be one primary hypothalamic target for a TRH-mediated decrease of food intake and body weight, mediated by local GABAergic neurons excited by TRH.

Although sleep-wake cycles and food intake in some contexts may seem unrelated, a primary role for sleep may be conservation of energy. Hcrt excites $\mathrm{MCH}$ neurons (van den Pol et al., 2004); here we found that TRH attenuates this excitation. This would be consistent with a model of TRHinduced arousal mediated by multiple parallel circuits, including direct activation of the arousal hypocretin neurons (González et al., 2009; Hara et al., 2009), which is complemented by inhibition of pro-sleep MCH neurons (present study), and a further attenuation of hypocretinmediated excitation of $\mathrm{MCH}$ cells (present study). Together, these multiple sites of TRH action enhance the differential response of the two opposing $[\mathrm{MCH}$ and hypocretin] systems.

\section{References}

Acuna-Goycolea C, Tamamaki N, Yanagawa Y, Obata K, van den Pol AN (2005) Mechanisms of neuropeptide $\mathrm{Y}$, peptide $\mathrm{YY}$, and pancreatic polypeptide inhibition of identified green fluorescent protein-expressing GABA neurons in the hypothalamic neuroendocrine arcuate nucleus. J Neurosci 25:7406-7419.

Ahnaou A, Drinkenburg WH, Bouwknecht JA, Alcazar J, Steckler T, Dautzenberg FM (2008) Blocking melanin-concentrating hormone $\mathrm{MCH} 1$ receptor affects rat sleep-wake architecture. Eur J Pharmacol 579:177-188.

Bäckberg M, Ultenius C, Fritschy JM, Meister B (2004) Cellular localization of GABA receptor alpha subunit immunoreactivity in the rat hypothalamus: relationship with neurones containing orexigenic or anorexigenic peptides. J Neuroendocrinol 16:589-604.

Bittencourt JC, Presse F, Arias C, Peto C, Vaughan J, Nahon JL, Vale W, Sawchenko PE (1992) The melanin-concentrating hormone system of the rat brain: an immuno- and hybridization histochemical characterization. J Comp Neurol 319:218-245.

Borowsky B, Durkin MM, Ogozalek K, Marzabadi MR, DeLeon J, Lagu B, Heurich R, Lichtblau H, Shaposhnik Z, Daniewska I, Blackburn TP, Branchek TA, Gerald C, Vaysse PJ, Forray C (2002) Antidepressant, anxiolytic and anorectic effects of a melanin-concentrating hormone- 1 receptor antagonist. Nat Med 8:825-830.

Castañeda TR, Jurgens H, Wiedmer P, Pfluger P, Diano S, Horvath TL, TangChristensen M, Tschop MH (2005) Obesity and the neuroendocrine control of energy homeostasis: the role of spontaneous locomotor activity. J Nutr 135:1314-1319.

Cowley MA, Smart JL, Rubinstein M, Cerdán MG, Diano S, Horvath TL, Cone RD, Low MJ (2001) Leptin activates anorexigenic POMC neurons through a neural network in the arcuate nucleus. Nature 411:480-484.

Della-Zuana O, Presse F, Ortola C, Duhault J, Nahon JL, Levens N (2002) Acute and chronic administration of melanin-concentrating hormone enhances food intake and body weight in Wistar and Sprague-Dawley rats. Int J Obes Relat Metab Disord 26:1289-1295.

Elias CF, Lee CE, Kelly JF, Ahima RS, Kuhar M, Saper CB, Elmquist JK (2001) Characterization of CART neurons in the rat and human hypothalamus. J Comp Neurol 432:1-19.

Elmquist JK, Bjørbaek C, Ahima RS, Flier JS, Saper CB (1998) Distributions of leptin receptor mRNA isoforms in the rat brain. J Comp Neurol 395:535-547.

Ervin GN, Schmitz SA, Nemeroff CB, Prange AJ Jr (1981) Thyrotropinreleasing hormone and amphetamine produce different patterns of behavioral excitation in rats. Eur J Pharmacol 72:35-43.

Fekete C, Légrádi G, Mihály E, Huang QH, Tatro JB, Rand WM, Emerson CH, Lechan RM (2000) alpha-Melanocyte-stimulating hormone is contained in nerve terminals innervating thyrotropin-releasing hormonesynthesizing neurons in the hypothalamic paraventricular nucleus and 
prevents fasting-induced suppression of prothyrotropin-releasing hormone gene expression. J Neurosci 20:1550-1558.

Fekete C, Kelly J, Mihály E, Sarkar S, Rand WM, Légrádi G, Emerson CH, Lechan RM (2001) Neuropeptide $Y$ has a central inhibitory action on the hypothalamic-pituitary-thyroid axis. Endocrinology 142:2606-2613.

Forray C (2003) The MCH receptor family: feeding brain disorders? Curr Opin Pharmacol 3:85-89.

González JA, Horjales-Araujo E, Fugger L, Broberger C, Burdakov D (2009) Stimulation of orexin/hypocretin neurones by thyrotropin-releasing hormone. J Physiol 587:1179-1186.

Guan JL, Uehara K, Lu S, Wang QP, Funahashi H, Sakurai T, Yanagizawa M, Shioda S (2002) Reciprocal synaptic relationships between orexin- and melanin-concentrating hormonecontaining neurons in the rat lateral hypothalamus: a novel circuit implicated in feeding regulation. Int J Obes Relat Metab Disord 26:1523-1532.

Hara J, Gerashchenko D, Wisor JP, Sakurai T, Xie X, Kilduff TS (2009) Thyrotropin-releasing hormone increases behavioral arousal through modulation of hypocretin/orexin neurons. J Neurosci 29:3705-3714.

Harthoorn LF, Sañé A, Nethe M, Van Heerikhuize JJ (2005) Multi-transcriptional profiling of melanin-concentrating hormone and orexincontaining neurons. Cell Mol Neurobiol 25:1209-1223.

Hassani OK, Lee MG, Jones BE (2009) Melaninconcentrating hormone neurons discharge in a reciprocal manner to orexin neurons across the sleep-wake cycle. Proc Natl Acad Sci U S A 106:2418-2422.

Hassani OK, Henny P, Lee MG, Jones BE (2010) GABAergic neurons intermingled with orexin and $\mathrm{MCH}$ neurons in the lateral hypothalamus discharge maximally during sleep. Eur J Neurosci 32:448-457.

Horita A (1998) An update on the CNS actions of TRH and its analogs. Life Sci 62:1443-1448.

Ishibashi H, Nakahata Y, Eto K, Nabekura J (2009) Excitation of locus coeruleus noradrenergic neurons by thyrotropin-releasing hormone. J Physiol 587:5709-5722.

Ito M, Gomori A, Ishihara A, Oda Z, Mashiko S, Matsushita H, Yumoto M, Ito M, Sano H, Tokita S, Moriya M, Iwaasa H, Kanatani A (2003) Characterization of MCH-mediated obesity in mice. Am J Physiol Endocrinol Metab 284:E940-E945.

Klootwijk W, Vaessen LM, Bernard BF, Rondeel JM, De Greef WJ, Visser TJ (1995) Production and characterization of monoclonal and polyclonal antibodies against thyrotropin-releasing hormone. Hybridoma 14:285-290.

Kraft R (2007) The $\mathrm{Na}+/ \mathrm{Ca}^{2+}$ exchange inhibitor KB-R7943 potently blocks TRPC channels. Biochem Biophys Res Commun 361:230-236.

Lagos P, Torterolo P, Jantos H, Chase MH, Monti JM (2009) Effects on sleep of melanin-concentrating hormone $(\mathrm{MCH})$ microinjections into the dorsal raphe nucleus. Brain Res 1265:103-110.

Lechan RM, Fekete C (2006) The TRH neuron: a hypothalamic integrator of energy metabolism. Prog Brain Res 153:209-235.

Lechan RM, Jackson IM (1982) Immunohistochemical localization of thyrotropin-releasing hormone in the rat hypothalamus and pituitary. Endocrinology 111:55-65.

Lechan RM, Wu P, Jackson IM (1986) Immunolocalization of the thyrotropin-releasing hormone prohormone in the rat central nervous system. Endocrinology 119:1210-1216.

Lee MG, Hassani OK, Jones BE (2005) Discharge of identified orexin/ hypocretin neurons across the sleep-waking cycle. J Neurosci 25:6716-6720.

Légrádi G, Lechan RM (1998) The arcuate nucleus is the major source for neuropeptide Y-innervation of thyrotropin-releasing hormone neurons in the hypothalamic paraventricular nucleus. Endocrinology 139:3262-3270.

Li Y, van den Pol AN (2009) Enhanced excitatory input to melanin concentrating hormone neurons during developmental period of high food intake is mediated by GABA. J Neurosci 29:15195-15204.

Li Y, Gao XB, Sakurai T, van den Pol AN (2002) Hypocretin/Orexin excites hypocretin neurons via a local glutamate neuron-A potential mechanism for orchestrating the hypothalamic arousal system. Neuron 36:1169-1181.

Lyons DJ, Horjales-Araujo E, Broberger C (2010) Synchronized network oscillations in rat tuberoinfundibular dopamine neurons: switch to tonic discharge by thyrotropin-releasing hormone. Neuron 65:217-229.

Moragues N, Ciofi P, Lafon P, Tramu G, Garret M (2003) GABAA receptor epsilon subunit expression in identified peptidergic neurons of the rat hypothalamus. Brain Res 967:285-289.

Morley JE (1980) The neuroendocrine control of appetite: the role of the endogenous opiates, cholecystokinin, TRH, gamma-amino-butyric-acid and the diazepam receptor. Life Sci 27:355-368.

Nillni EA, Vaslet C, Harris M, Hollenberg A, Bjørbak C, Flier JS (2000) 
Leptin regulates prothyrotropin-releasing hormone biosynthesis. Evidence for direct and indirect pathways. J Biol Chem 275:36124-36133.

Nishino S, Arrigoni J, Shelton J, Kanbayashi T, Dement WC, Mignot E (1997) Effects of thyrotropin-releasing hormone and its analogs on daytime sleepiness and cataplexy in canine narcolepsy. J Neurosci 17:6401-6408.

Nishiyama T, Kawano H, Tsuruo Y, Maegawa M, Hisano S, Adachi T, Daikoku S, Suzuki M (1985) Hypothalamic thyrotropin-releasing hormone (TRH)-containing neurons involved in the hypothalamic-hypophysialthyroid axis. Light microscopic immunohistochemistry. Brain Res 345:205-218.

Niu CF, Watanabe Y, Ono K, Iwamoto T, Yamashita K, Satoh H, Urushida T, Hayashi H, Kimura J (2007) Characterization of SN-6, a novel Na+/ $\mathrm{Ca}^{2+}$ exchange inhibitor in guinea pig cardiac ventricular myocytes. Eur J Pharmacol 573:161-169.

Parmentier R, Kolbaev S, Klyuch BP, Vandael D, Lin JS, Selbach O, Haas HL, Sergeeva OA (2009) Excitation of histaminergic tuberomamillary neurons by thyrotropin-releasing hormone. J Neurosci 29:4471-4483.

Perello M, Stuart RC, Nillni EA (2006) The role of intracerebroventricular administration of leptin in the stimulation of prothyrotropin releasing hormone neurons in the hypothalamic paraventricular nucleus. Endocrinology 147:3296-3306.

Presse F, Sorokovsky I, Max JP, Nicolaidis S, Nahon JL (1996) Melaninconcentrating hormone is a potent anorectic peptide regulated by fooddeprivation and glucopenia in the rat. Neuroscience 71:735-745.

Qiu J, Fang Y, Rønnekleiv OK, Kelly MJ (2010) Leptin excites proopiomelanocortin neurons via activation of TRPC channels. J Neurosci 30:1560-1565.

Qu D, Ludwig DS, Gammeltoft S, Piper M, Pelleymounter MA, Cullen MJ, Mathes WF, Przypek R, Kanarek R, Maratos-Flier E (1996) A role for melanin-concentrating hormone in the central regulation of feeding behaviour. Nature 380:243-247.

Reichlin S (1989) TRH: historical aspects. Ann N Y Acad Sci 553:1-6.

Rossi M, Beak SA, Choi SJ, Small CJ, Morgan DG, Ghatei MA, Smith DM, Bloom SR (1999) Investigation of the feeding effects of melanin concentrating hormone on food intake-action independent of galanin and the melanocortin receptors. Brain Res 846:164-170.

Saito Y, Nothacker HP, Wang Z, Lin SH, Leslie F, Civelli O (1999) Molecular characterization of the melanin-concentrating-hormone receptor. Nature 400:265-269.

Sakurai T, Amemiya A, Ishii M, Matsuzaki I, Chemelli RM, Tanaka H, Williams SC, Richardson JA, Kozlowski GP, Wilson S, Arch JR, Buckingham
RE, Haynes AC, Carr SA, Annan RS, McNulty DE, Liu WS, Terrett JA, Elshourbagy NA, Bergsma DJ, et al. (1998) Orexins and orexin receptors: a family of hypothalamic neuropeptides and G protein-coupled receptors that regulate feeding behavior. Cell 92:573-585.

Segal-Lieberman G, Bradley RL, Kokkotou E, Carlson M, Trombly DJ, Wang X, Bates S, Myers MG Jr, Flier JS, Maratos-Flier E (2003) Melaninconcentrating hormone is a critical mediator of the leptin-deficient phenotype. Proc Natl Acad Sci U S A 100:10085-10090.

Steward CA, Horan TL, Schuhler S, Bennett GW, Ebling FJ (2003) Central administration of thyrotropin releasing hormone (TRH) and related peptides inhibits feeding behavior in the Siberian hamster. Neuroreport 14:687-691.

Suply T, Della Zuana O, Audinot V, Rodriguez M, Beauverger P, Duhault J, Canet E, Galizzi JP, Nahon JL, Levens N, Boutin JA (2001) SLC-1 receptor mediates effect of melanin-concentrating hormone on feeding behavior in rat: a structure-activity study. J Pharmacol Exp Ther 299:137-146.

Suzuki T, Kohno H, Sakurada T, Tadano T, Kisara K (1982) Intracranial injection of thyrotropin releasing hormone (TRH) suppresses starvationinduced feeding and drinking in rats. Pharmacol Biochem Behav 17:249-253.

van den Pol AN, Acuna-Goycolea C, Clark KR, Ghosh PK (2004) Physiological properties of hypothalamic MCH neurons identified with selective expression of reporter gene after recombinant virus infection. Neuron 42:635-652.

van den Pol AN, Yao Y, Fu LY, Foo K, Huang H, Coppari R, Lowell BB, Broberger C (2009) Neuromedin B and gastrin-releasing peptide excite arcuate nucleus neuropeptide $\mathrm{Y}$ neurons in a novel transgenic mouse expressing strong Renilla green fluorescent protein in NPY neurons. J Neurosci 29:4622-4639.

Verret L, Goutagny R, Fort P, Cagnon L, Salvert D, Léger L, Boissard R, Salin P, Peyron C, Luppi PH (2003) A role of melanin-concentrating hormone producing neurons in the central regulation of paradoxical sleep. BMC Neurosci 4:19.

Vijayan E, McCann SM (1977) Suppression of feeding and drinking activity in rats following intraventricular injection of thyrotropin releasing hormone (TRH). Endocrinology 100:1727-1730.

Vogel RA, Cooper BR, Barlow TS, Prange AJ Jr, Mueller RA, Breese GR (1979) Effects of thyrotropin-releasing hormone on locomotor activity, operant performance and ingestive behavior. J Pharmacol Exp Ther 208:161-168.

Wei E, Sigel S, Loh H, Way EL (1975) Thyrotrophin-releasing hormone and shaking behaviour in rat. Nature 253:739-740. 